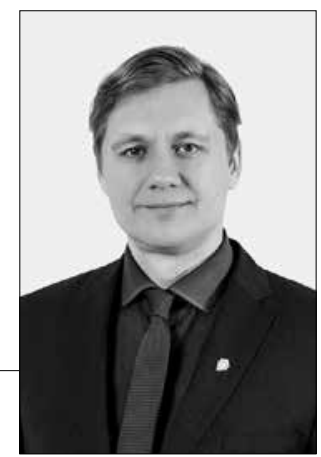

\title{
TEISÉ I TOS PAČIOS LYTIES SUTUOKTINIŲ SUSIJUNGIMĄ ARBA DAR KARTĄ APIE KONSTITUCIJOS INTERPRETAVIMĄ: VIENO KONSTITUCINIO TEISMO NUTARIMO ATVEJIS
}

\author{
The Right to Reunification of Same-Sex Spouses in Context \\ of Lithuanian Law on Legal Status of Foreigners or Again on \\ Interpretation of Constitution: Case of one Constitutional Court Ruling
}

SUMMARY

In this article, the Constitutional Court ruling of January 11, 2019 is analyzed not only from the perspective of the constitutional concept of family and marriage, but also from the broader perspective of Constitution interpretation, including aspects such as the relationship between constitutional principles and constitutional norms, the role of international and EU law in interpreting the Constitution, and the possibility of judicial dialogue in the jurisprudence of the Constitutional Court. The conclusions of the article ends with some methodology of interpretation of the Constitution, which can be applied not only to the constitutional concept of marriage and family, but also to all other provisions of the Constitution under interpretation.

\section{SANTRAUKA}

Šiame straipsnyje 2019 m. sausio 11 d. Konstitucinio Teismo nutarimas analizuojamas ne tik ir ne tiek iš šeimos bei santuokos konstitucinės sampratos perspektyvos, bet žvelgiant į ši nutarimą plačiau, t.y. per Konstitucijos interpretavimo prizmę, apimant tokius aspektus, kaip konstitucinių principų ir normų santykis, 
tarptautinės ir ES teisės įtaka aiškinant Konstituciją bei teisminio dialogo galimybẻ Konstitucinio Teismo jurisprudencijoje. Straipsnio išvadose pateikiamos tam tikros nuostatos dèl Konstitucijos interpretavimo metodologijos, kurią galima pritaikyti ne tik santuokos ir šeimos konstitucinei sampratai, bet ir aiškinant visas kitas Konstitucijos nuostatas.

\section{IVADAS}

Dar 2017 metais Lietuvos žiniasklaidoje pasirodè informacija apie ginčą vienoje administracinejje byloje, kai Migracijos departamentas prie Lietuvos Respublikos Vidaus Ministerijos (Migracijos departamentas) atsisakè išduoti leidimą laikinai gyventi Lietuvoje (šeimos susijungimo pagrindu) Baltarusijos piliečiui, kuris 2015 metais Danijoje sudare santuoką su tos pačios lyties Lietuvos Respublikos piliečiu. Migracijos departamentas tokị savo sprendimą rèmė konstitucine santuokos samprata, pagal kurią sutuoktiniais Lietuvoje gali būti laikomi tik vyras ir moteris. Minèti asmenys apskundè toki Migracijos departamento sprendima, kuri pirmos instancijos teismas paliko galioti, o Lietuvos vyriausiasis administracinis teismas (LVAT) nusprende kreiptis į Konstitucinį Teismą su klausimu dèl legislatyvinès omisijos, t. y. klausdamas, ar tai, kad įstatymo „Dèl užsieniečių teisinès padèties" 43 straipsnio 1 d. 5 punktas nenumato galimybès išduoti leidimo laikinai gyventi Lietuvoje užsieniečiui (šeimos susijungimo atveju), kai jis užsienio valstybèje yra susituokęs su tos pačios lyties Lietuvos piliečiui, neprieštarauja Lietuvos Respublikos Konstitucijai. 2019 m. sausio 11 d. nutarime Konstitucinis Teismas nusprendè nenagrinèti legislatyvinès omisijos klausimo, o pasisakyti dèl minèto ístatymo nuostatos, teigiančios, kad „leidi- mas laikinai gyventi gali būti išduodamas užsieniečiui šeimos susijungimo atveju [...], kai Lietuvos Respublikoje gyvena užsieniečio sutuoktinis, kuris yra Lietuvos Respublikos pilietis". Taigi, Konstitucinis Teismas nusprendè, kad „užsieniečio sutuoktinis, kuris yra Lietuvos Respublikos pilietis“, šio istatymo kontekste apima ir tą kuris užsienyje susituokęs su tos pačios lyties asmeniu.

Tuo pačiu Konstitucinis Teismas šiame nutarime konstatavo, jog toks „sutuoktinio" termino reikšmès išplètimas gali būti taikomas tik užsieniečio judejjimo laisvès, numatytos isstatymo „Dèl užsieniečiu teisinès padèties“", pagrindu ir „negali būti aiškinamas kaip keičiantis Konstitucijos 38 straipsnio 3 dalyje ịtvirtintą santuokos sampratą" (pagal kurią santuoka gali būti sukurta tik vyro ir moters laisvu sutarimu). Taip pat Konstitucinis Teismas konstatavo, jog šis nutarimas nereiškia, kad tos pačios lyties užsieniečio ir Lietuvos Respublikos piliečio užsienyje sudaryta santuoka pagal Konstituciją turi būti ịtraukta į apskaitą Lietuvos Respublikos civilinès metrikacijos ịstaigoje. Taip pat Teismas pripažino, jog atsižvelgiant i objektyvius ir konstituciškai pagrisstus kriterijus, gali būti nustatytas diferencijuotas valstybės globos ir paramos šeimai teisinis reguliavimas. Vis dèlto, kaip matysime vèliau, abejotina, kad terminas „sutuoktinis“ 
gali turèti skirtingą reikšmę pagal Lietuvos Konstituciją kad santuoką sudaryti Lietuvoje gali tik skirtingų lyčiu asmenys, o pagal minètą i̇statymą - kad Lietuvos institucijos turi pripažinti Lietuvos Respublikos piliečio santuoka, sudarytą užsienyje su tos pačios lyties asmeniu, kaip sukuriančią šeimos santykius (šiuo atveju - judèjimo laisvès kontekste).

Šis straipsnis iš dalies yra tęsinys ankstesnio autoriaus straipsnio „Šiuolaikinio konstitucionalizmo samprata" (Vaičaitis 2017). Kalbant apie straipsnyje analizuojamų problemų ištirtinumo lygi Lietuvos konstitucinès teisès mokslo publikacijose, reikia pasakyti, jog apie konstitucines nor- mas ir principus rašè Egidijus Kūris (Kūris 2001; 2002; 2004), apie „ekstrakonstitucinius" šaltinius, interpretuojant Konstitucija, rašè Ronaldas Dworkinas (Dworkin 2005), konstitucinius principus nagrinèjo Robertas Alexy (Alexy 2010), santuokos ir šeimos konstitucinè samprata Lietuvoje buvo analizuota tik fragmentiškai (Sagatys 2010; Jarašiūnas 2011, Vaičaitis 2012), apie tos pačios lyties santuokas sudariusiu asmenu judejimo laisvę pagal ES teisę rašè Loreta Šaltinytė (Lietuvos teisè 2018: esminiai pokyčiai 2019), o teisminis dialogas, kaip atskiras reiškinys, kol kas praktiškai nesulaukè Lietuvos teisès mokslo atidesnio dèmesio (Vaičaitis 2017).

\section{1. ŠEIMOS IR SANTUOKOS INSTITUTŲ KONSTITUCINĖ SAMPRATA}

Kaip jau buvo minèta, šioje konstitucinès justicijos byloje pareiškejas suabejojo, ar ịstatymo „Dèl užsieniečiu teisinès padèties" reguliavimas, tiksliau, legislatyvinè omisija, t. y. tai, kas pareiškejjo žodžiais tariant, "nèra nustatyta“ (dèl tos pačios lyties asmenų užsienyje registruotos santuokos ar partnerystės pripažinimo šeimos santykiais šio i̇statymo 43 str. 1 dalies prasme), be kita ko, atitinka Konstitucinio Teismo $2011 \mathrm{~m}$. rugsèjo 28 d. nutarime suformuluotą konstitucinès jurisprudencijos nuostata, pagal kurią ",konstitucinè šeimos samprata grindžiama šeimos narių tarpusavio atsakomybe, supratimu, emociniu prieraišumu, pagalba ir panašiais ryšiais bei savanorišku apsisprendimu prisiimti tam tikras teises ir pareigas, t. y. santykiu turiniu, o šių santykiu išraiškos forma konstitucinei šeimos sampratai esminès reikšmès neturi“. Kaip matysime vèliau, toks pa- reiškejjo pateiktas $2011 \mathrm{~m}$. rugsèjo $28 \mathrm{~d}$. Konstitucinio Teismo nutarimo citavimas yra nepilnas, nes jame nepaminèta, kad jame konstitucinè šeimos samprata siejama, be kita ko, su „vyro ir moters bendru gyvenimu“. Nežiūrint to, šiame nutarime Konstitucinis Teismas konstatavo, jog pagal Konstitucija, minètą įstatymą „Dèl užsieniečių teisinès padèties“ reikia suprasti taip, kad leidimas laikinai gyventi užsieniečiui šeimos susijungimo atveju gali būti išduodamas ir tada, kai Lietuvos Respublikoje gyvena tokio užsieniečio tos pačios lyties Lietuvos Respublikos pilietis, su kuriuo kitoje valstybejje teisètai buvo sudaryta santuoka ar registruotos partnerystès sutartis. Ši teigini Konstitucinis Teismas grinde tuo, jog šioje konstitucinès justicijos byloje aktuali yra ne santuokos, o šeimos konstitucinè samprata, kuri „be kita ko, yra neutrali lyties požiūriu“. Beje, išvesda- 
mas pastarająa šeimos „neutralumo lyties požiūriu" sampratą, Teismas rèmèsi Europos Sajungos Teisingumo Teismo jurisprudencija, visu pirma jo $2018 \mathrm{~m}$. birželio $5 \mathrm{~d}$. sprendimu byloje C-673/16 Coman ir kt. Tačiau, kaip matysime vèliau, tokia pozicija galimai neatitinka Lietuvos Respublikos Konstitucijos tiek turinio, tiek ir jos viršenybès kitu teisès aktų atžvilgiu.

Tiesa, prieš pateikiant sistemini požiūrị i konstitucinès šeimos samprata, čia galima priminti, jog Teismas šiame nutarime nekvestionavo Konstitucijos 38 straipsnio 3 dalies nuostatos, kurioje yra itvirtinta kad santuoka sudaroma laisvu vyro ir moters sutarimu ir pripažino, kad „kitokia santuokos samprata Lietuvos Respublikos isstatymuose negali būti itvirtinta atitinkamai nepakeitus Konstitucijos 38 straipsnio 3 dalies". Tačiau, kaip jau buvo minèta, ši teigini Konstitucinis Teismas praktiškai paneige kitu teiginiu, t. y. konstatuodamas, jog leidimas laikinai gyventi užsieniečiui, „,̌̌eimos susijungimo atveju" (minèto İstatymo prasme) gali būti išduodamas, kai Lietuvos Respublikoje gyvena tos pačios lyties Lietuvos pilietis, su kuriuo kitoje valstybeje teisètai sudaryta santuoka.

Visu pirma čia kyla klausimas, ar šioje byloje esminis tyrimo objektas buvo konstitucinè šeimos samprata, ar konstitucinè santuokos samprata? Manytina, jog pagrindinis objektas šioje byloje buvo būtent Konstitucijos 38 straipsnio 3 dalies nuostata, jog "santuoka sudaroma laisvu vyro ir moters sutarimu" todèl, kad Konstitucinis Teismas čia ėmèsi aiškinti Istatymo nuostatą apie Lietuvos pilieti - užsieniečio sutuoktini, t. y., kad „leidimas laikinai gyventi gali būti išduodamas užsieniečiui šeimos susijungimo atveju [...], kai Lietuvos Respublikoje gyvena užsieniečio sutuoktinis, kuris yra Lietuvos Respublikos pilietis“. Taigi, Migracijos departamentas (istatymo 43 str. 1 dalies kontekste), nustatydamas šeimos ryšių egzistavimo faktą, galejo remtis tik jam pateiktu dokumentu, patvirtinančiu apie užsienyje registruotą šių dviejų asmenų santuoka, o ne atlikinèti tyrimą dèl dvieju asmenų faktinių santykiu nustatymo. Todèl šioje konstitucinės justicijos byloje vertinimo atskaitos taškas yra tai, ar Lietuvos migracijos departamentui reikia užsienyje sudarytą santuoka su tos pačios lyties užsieniečiu sudariusi Lietuvos pilietị laikyti šeima Lietuvos Konstitucijos prasme. Taigi, Konstitucinio Teismo argumentai apie šeimos konstitucinę sampratą šiame nutarime tiek, kiek jie nebuvo susijęs su santuokos samprata, galètų būti vertina$\mathrm{mi}$, kaip obiter dicta motyvai, nes jie nèra tiesiogiai susiję su šios bylos pagrindine konstitucingumo problema. Tačiau, kadangi Konstitucinis Teismas šiame nutarime pagrindinį akcentą siejo būtent su konstitucinès šeimos samprata, todèl būtina čia kiek detaliau ją aptarti.

Taigi, sistemiškai žvelgiant i Lietuvos Respublikos Konstituciją galima konstatuoti, jog santuoka Lietuvoje nèra vienintelè šeimos santykių sukūrimo forma (38 str. 3 dalis), nes be jos Konstitucija numato ir antrą šeimos atsiradimo pagrindą - motinystès bei tèvystès institutą (38 str. 2 dalis), t. y. tėvų-vaikų santykius, atsiradusius iš vaiku gimimo ir/ar isivaikinimo, nepriklausomai nuo santuokos sudarymo fakto. Be to, Konstitu- 
cijoje yra įtvirtintas svarbus sutuoktiniu teisių lygybės principas bei tèvų ir vaiku tarpusavio teisiu ir pareigu institutas, ipareigojantis pirmuosius ",auklèti ir išlaikyti" vaikus iki pilnametystès, o antruosius "gerbti tèvus ir globoti juos senatvèje“" (Konstitucijos 38 str. 5-7 d.). Manytina, jog panašiai pozicijai pritare ir Konstitucinis Teismas jau minèto $2011 \mathrm{~m}$. rugsèjo $28 \mathrm{~d}$. nutarimo dviejose vietose, konstatavęs, „kad pagal Konstitucija, inter alia jos 38 straipsnio nuostatas, santuoka yra vienas iš šeimos konstitucinio instituto pagrindų kurti šeimos santykius, tačiau tai nereiškia, kad Konstitucija, inter alia jos 38 straipsnio 1 dalies nuostatos, nesaugo ir negina kitokiu nei santuokos pagrindu sudarytu šeimu, inter alia santuokos nesudariusiu vyro ir moters bendro gyvenimo, kuris grindžiamas pastoviais emocinio prieraišumo, tarpusavio supratimo, atsakomybès, pagarbos, vaiku bendro auklejjimo ir panašiais ryšiais bei savanorišku apsisprendimu prisiimti tam tikras teises ir pareigas, kurie yra konstituciniu motinystès, tèvystės ir vaikystės institutu pagrindas". Taigi minètame Konstitucinio Teismo nutarime Teismas konstitucinę šeimos sampratą (be santuokos) dar siejo ir su „,santuokos neiregistravusių bendrai gyvenančių vyro ir moters, ju vaikų (ivaikių), vieno iš tèvų, auginančio vaiką (ivaikị), ir kt.“

Tuo tarpu $2019 \mathrm{~m}$. sausio $11 \mathrm{~d}$. nutarime Teismas ị konstitucinę šeimos sampratą papildè teisine novela, teigdamas, kad „konstituciné šeimos samprata, be kita ko, yra neutrali lyties požiūriu", nepaminèdamas $2011 \mathrm{~m}$. rugsëjo $28 \mathrm{~d}$. nutarime šeimos konstitucinès sampratos formuluotèje i̇vardintų "santuokos neį- registravusiu bendrai gyvenančiu vyro ir moters, jų vaiku (ivaikių), vieno iš tèvu, auginančio vaiką (ìvaikị)". Be to, Teismas šiame nutarime konstitucinę šeimos sampratą susiejo su tokiomis sociologinio ir ideologinio pobūdžio sąvokomis, kaip asmenu "lytinè tapatybe ir (ar) seksualinè orientacija" bei vertinimais apie "vyraujančias daugumos visuomenès nariu nuostatas ar stereotipus". Vis dèlto, šio straipsnio kontekste pasakytina, jog Konstitucinis Teismas gali keisti savo precedentus, tačiau tam būtina, kad jis tokị savo sprendimą nukrypti nuo precedento konstituciškai pagrịstu. Dèl šios priežasties Teismo teigini apie konstitucinę šeimos samprata, kaip „neutralią lyties požiūriu“, galima būtų suprasti kaip taikomą išimtinai motinystės, tėvystės ir vaikystės konstituciniam institutui (t. y. tėvų-vaikų santykiams), o ne šeimos partneriams.

Taigi grižkime prie konstitucinès šeimos sampratos. Čia galètume išskirti dvejopą "požiūrio kampą" i šeimos instituta, t. y. kad Konstitucija į šeimą žvelgia: 1) per žmogaus teisiu prizmę ir 2) kaip i autonominę sui generis konstitucinę vertybę. Pirmasis (žmogaus teisių) požiūris į šeimą atsispindi Konstitucijos 22 straipsnyje, kur „šeimyninis gyvenimas" siejamas su žmogaus privatumu; taip pat 31 straipsnyje, kuriame įtvirtintas draudimas versti duoti parodymus prieš savo šeimos narius, ir 117 straipsnyje, îtvirtinančiame šeimyninio gyvenimo slaptumo apsaugą bei 146 straipsnyje, garantuojančiame socialinę ir/ar finansinę paramą žuvusių ar mirusių karių bei valstybės gynëju likusiems šeimos nariams. Tuo tarpu antrasis (šeimos, kaip sui generis konstitucinès vertybės) požiū- 
ris atsispindi Konstitucijos 111 straipsnyje, numatančiame galimybę Lietuvoje steigti šeimos specializuotus teismus bei 38-39 straipsniuose, kuriuose ittvirtinta valstybės pareiga teikti globą šeimai. Paminètina, jog abi šios šeimos sampratos konstitucinės perspektyvos neprieštarauja, o papildo viena kitą.

Tačiau stipriausiai šeimos, kaip autonomiškos konstitucinès vertybès, samprata atsispindi 38 straipsnio 1 dalies nuostatoje, teigiančioje, kad „šeima yra visuomenės ir valstybės pagrindas". Ši nuostata visu pirma reiškia tai, kad valstybė pripažista šeimos santykių autonomiją ir teikia jai visokeriopą paramą. Būtent todèl Konstitucijos 26 str. 5 dalyje yra numatyta, jog tėvai ir globejjai nevaržomi rūpinasi vaikų ir globotiniu religiniu ir doroviniu auklejjimu pagal savo isitikinimus, o 40 straipsnyje - kad valstybinėse ir savivaldybių mokyklose tikybos mokoma "tèvų pageidavimu“, o ne mokyklai ar valstybei nusprendus. Beje, Konstitucija daugiau jokio kito konstitucinio instituto neįvardina „valstybès ir visuomenės pagrindu“. Iš Konstitucijos galime daryti išvada, kad toks ypatingas dèmesys šeimai joje ittvirtintas greičiausiai todèl, kad šeima (o ne valstybès institucijos ar kita socialinè aplinka) yra pagrindinè vaikų kaip būsimų visuomenės narių socializacijos, augimo ir auklejjimosi „dorais žmonėmis ir ištikimais piliečiais" vieta. Beje, toks požiūris atsispindi ir 39 straipsnyje, kuris globą ir paramą šeimoms sieja būtent su vaikų auginimu ir auklejjimu.

Kadangi straipsnyje jau pradèta analizuoti Konstitucijos aiškinimo metodologija, tai ši klausimą būtina aptarti atskiroje dalyje.

\section{KONSTITUCINIAI PRINCIPAI, KONSTITUCINĖS NORMOS IR KONSTITUCIJOS INTERPRETAVIMAS}

Kaip žinia, Konstituciją sudaro tarpusavyje susiję konstituciniai principai ir konstitucinès normos. Konstituciniu principų ir normų tarpusavio santykio klausimas iškilo skaitant pareiškejjo (LVAT) kreipimosi ị Konstitucini Teismą motyvus, kurie rèmési galimu legislatyvinès omisijos konstatavimu, t. y. tuo, kas istatyme "Dèl užsieniečių teisinès padèties" néra nustatyta. Taigi, viena vertus, LVAT teigè, jog leidimas laikinai gyventi užsieniečiui, užsienyje sudariusiam santuoką su tos pačios lyties Lietuvos piliečiu šeimos susijungimo atveju Lietuvoje neišduodamas "dèl draudimo tuoktis tos pačios lyties asmenims" (numatyto Kons- titucijos 38 str. 3 dalyje), o kita vertus, LVAT teigè, jog toks šeimos santykių nepripažinimas (minèto įstatymo kontekste) galimai prieštarauja Konstitucijos 22 straipsnio 1, 4 dalims, 29 straipsniui, 38 straipsnio 1, 2 dalims bei konstituciniam teisinès valstybės principui. Taigi, iš tiesu pareiškèjas čia kèlè ne legislatyvinès omisijos klausima, o klausimą apie Konstitucijos 38 str. 3 dalyje numatytos normos (kad santuoką gali sudaryti tik vyras ir moteris) santyki su konstituciniais principais (t. y. žmogaus privataus gyvenimo apsaugos, lygiateisiškumo ir teisinès valstybės). Kitaip tariant, čia buvo klausiama dèl Konstitucijos normų ir principų tarpu- 
savio santykio darnos, o ne dèl legislatyvinès omisijos, nes pastarosios konstatavimas minėtame istatyme (t. y. tiek, kiek istatyme kas nors „nenustatyta“) niekaip nebūtų galëjęs išspręsti šio Konstitucijos vidinès darnos klausimo. Tačiau tuo atveju, jei konstitucinis principas konkuruoja su konstitucine norma, pastaroji turètu „,nusverti“ šioje konkurencijoje, nes abstraktaus pobūdžio principai paprastai negali būti tiesiogiai taikomi be juos sukonkretinančių normų. Kadangi Lietuvos Konstitucijos 38 str. 3 dalyje numatyta vyro ir moters santuokos konstitucine samprata yra ne tik konstitucinè vertybė, bet ir konstitucinè norma, labai aiškiai nustatanti, kokie asmenys pagal lyti (ir kiek tokių asmenų) gali Lietuvoje sudaryti santuoka, todèl šioje konstitucinių nuostatu konkurencijoje pirmumą reikia teikti būtent 38 str. 3 dalies normai, kad „santuoka sudaroma laisvu vyro ir moters sutari$\mathrm{mu}^{\prime \prime}$. Kitaip tariant, nei asmenu lygiateisiškumo, nei teisinès valstybès ar kiti konstituciniai principai negali paneigti minètos Konstitucijos 38 str. 3 dalies normos dèl santuokos, kaip vyro ir moters susitarimo.
Todèl vargu ar ši LVAT kreipimąsi i Konstitucinį Teismą galima būtų pripažinti tinkamai pagristu. Be to, nors Konstitucinis Teismas ne kartą sau yra pripažinęs legislatyvinès omisijos konstitucingumo tyrimo kompetencija, vis dèlto galima kelti klausima, ar šios praktikos ateityje nereikètú atsisakyti, nes tokia Konstitucinio Teismo funkcija nèra expressis verbis ivardinta Konstitucijoje. Pagaliau, įdomu šioje konstitucinės justicijos byloje yra ir tai, jog Konstitucinis Teismas, nusprendęs priimti nagrinèti šią bylą dèl legislatyvinès omisijos konstatavimo galimumo, to klausimo visai nesprendè, o tiesiog pateikè minèto istatymo nuostatos plečiamaji išaiškinimą.

Pagaliau šios dalies pabaigoje reikia pasakyti, jog atidžiau pažvelgę i analizuojamą Konstitucinio Teismo nutarima, galime pastebèti dar vieną (savarankišką) Teismo naudotą šeimos konstitucinès sampratos interpretavimo metodą - tai nuorodas i Europos teismų sprendimus, kas šiame straipsnyje bus vadinamas ",teisminio dialogo" argumentu, nusipelnančio atskiro dèmesio paskutinëje šio straipsnio dalyje.

\section{TEISMINIS DIALOGAS KONSTITUCINIO TEISMO NUTARIME IR KONSTITUCIJOS VIRŠENYBE்}

Taigi, šios, paskutinès, straipsnio dalies kontekste norètųsi atkreipti dèmesi i vadinamąj teisminio dialogo reiškini, kuris skatina teismus semtis patirties ne tik iš nacionalinių teismų, bet ir iš užsienio ar tarptautinių teismų praktikos. Toks požiūris svarbus todèl, kad paskutiniu metu, atsiradus daugiau teismu tarpusavio bendradarbiavimo formu (ypač tai pasakytina apie Europos konstitucinius teismus) bei internete anglų ir kitomis kalbomis publikuojant ivairių šalių aukščiausių ir konstitucinių teismų sprendimų vertimus, toks reiškinys, kaip teisminis dialogas, tapo daug lengvesnis. Dar daugiau, Europoje vadinamasis teisminio dialogo fenomenas apima ir Europos Žmogaus Teisių Teismo (EŽTT), o 
tarp Europos Sajungos valstybiu - ir Europos Sajungos Teisingumo Teismo (ESTT) sprendimu itaką formuojant nacionalinių teismų jurisprudenciją.

Ne išimtis yra ir Lietuvos Konstitucinis Teismas, kuris kartais savo sprendimuose cituoja Strasbūro teismo, o po 2004 metų - ir Liuksemburgo teismo praktiką. Štai Europos žmogaus teisių teismo sprendimai per 25-erius Konstitucinio Teismo veiklos metus (t. y. nuo 1993 iki 2020 metų) buvo cituojami daugiau nei trisdešimtyje Konstitucinio Teismo nutarimų ir keliose išvadose bei sprendimuose. Tuo tarpu Europos Sajungos Teisingumo Teismo jurisprudencija nuo 2006 iki 2020 metu (t. y. per dvigubai trumpesni laikotarpi) buvo cituota kiek daugiau nei dvidešimtyje nutarimų bei du kartus buvo kreiptasi į ESTT su prašymu priimti prejudicini sprendimą.

Lietuvos Konstitucinis Teismas savo aktuose kartais pateikia ir kitų Europos valstybių (dažniausiai ES valstybių narių) konstitucinių teismų su konkrečia konstitucinès justicijos byla susijusių sprendimų jurisprudencijos apžvalgą. Tiesa, jis tai daro daug rečiau nei dèl Strasbūro bei Liuksemburgo teismu doktrinos, nes galètume suskaičiuoti tik apie dešimti tokių Konstitucinio Teismo nutarimu, tarp ju jau minètą $2011 \mathrm{~m}$. rugsèjo $28 \mathrm{~d}$. nutarimą „Dèl Valstybinès šeimos politikos koncepcijos" nuostatų konstitucingumo, kuriame buvo pateikta ne tik Europos žmogaus teisių teismo susijusi jurisprudencija, bet ir Čekijos, Slovenijos, Kroatijos, Vengrijos ir Prancūzijos konstitucinès priežiūros organų sprendimai, susiję su šeimos sampratos analize. Tiesa, pastarosios analizès pabaigoje Konstitucinis Teismas apibendrino, jog šeimos sampra- tos aiškinimas minètų užsienio valstybių konstitucinių teismų jurisprudencijoje nèra vienareikšmis.

Iš tiesų reikia pripažinti, jog lyginamoji teisètyra, kaip mokslo šaka, yra labai svarbi, nes leidžia plačiau pažvelgti ì nacionalinę teisinę sistemą, todèl analogiškai galima būtų vertinti ir vadinamojo teisminio dialogo fenomeną, kuris, beje, sustiprina teisminès valdžios nepriklausomumą nuo įstatymų leidžiamosios ir vykdomosios valdžios, nes leidžia teismų sprendimus gristi ekstranacionaliniais teisès šaltiniais. Tačiau tokia praktika ne visada gali būti priimtina, nes teismo sprendimas remtis „ekstranacionaliniais" teisès šaltiniais gali prieštarauti nacionalinès konstitucijos viršenybės principui.

Jei grižtume prie 2019 m. sausio 11 dienos nutarimo, tai reikètų pažymèti, jog jo konstatuojamoji dalis susideda iš penkių dalių: „I. Ginčijamas ir su juo susijęs teisinis reguliavimas; II. Europos Sajungos teisès aktuose nustatytas teisinis reguliavimas ir Europos Sajungos Teisingumo Teismo jurisprudencija; III. Europos Tarybos teisès aktuose įtvirtintas teisinis reguliavimas ir Europos Žmogaus Teisių Teismo jurisprudencija; IV. Konstitucijos nuostatos ir oficialioji konstitucinè doktrina ir V. Istatymo „Dèl užsieniečių teisinès padèties" 43 straipsnio 1 dalies 5 punkto atitikties Konstitucijai vertinimas". Taigi, kaip matome, beveik pusę Konstitucinio Teismo nutarimo turinio apimties (jei neskaičiuosime pirmosios dalies), aiškinant Lietuvos Respublikos Konstitucija, sudaro ES teisès ir Europos žmogaus teisių konvencijos nuostatų bei aktualios Liuksemburgo ir Strasbūro teismų jurisprudencijos analizès pateikimas. 
Čia svarbu būtų atkreipti dèmesį i Konstitucinio Teismo nutarime pateiktą Europos Sajungos Teisingumo Teismo aktualią jurisprudencija iš kurios svarbiausias yra ESTT $2018 \mathrm{~m}$. birželio $5 \mathrm{~d}$. sprendimas byloje C-673/16 Coman ir kt., kuriame ESTT pateikè ES direktyvos 2004/38/EC (dèl judejjimo laisvès) išaiškinimą. I ESTT su prašymu priimti prejudicini sprendimą kreipęsis Rumunijos Konstitucinis Teismas prašè išaiškinti, ar Direktyvoje vartojama sąvoka "sutuoktinis" apima ir Europos Sajungos piliečio tos pačios lyties sutuoktini ne valstybès narès pilieti, su kuriuo Europos Sajungos pilietis teisètai susituokè pagal kitos valstybès narès teisę. Teigiamai atsakydamas i ši klausima, ESTT konstatavo, jog minèta Direktyva turi būti „,aiškinama kaip draudžianti valstybès narès, kurios pilietybę turi Sajungos pilietis, kompetentingoms valdžios institucijoms atsisakyti suteikti teisę gyventi tos valstybès narès teritorijoje minètam trečiosios šalies piliečiui, motyvuojant tuo, kad šios valstybès narès teiseje nenumatyta tos pačios lyties asmenų santuoka".

Taigi, čia reikia pripažinti, jog sąvoka "sutuoktinis" tikrai turi skirtingą teisini turini pagal ES Piliečiu direktyva, kaip ji buvo išaiškinta minètame ESTT sprendime, ir pagal Lietuvos Respublikos Konstitucija, tačiau tai nereiškia, kad ši Direktyva gali daryti ịtaką aiškinant Lietuvos Konstitucijos nuostatas (Loreta Šaltinytė 2019: 66), nes tokiu atveju galètų būti pažeistas Konstitucijos viršenybès principas.

Bet kuriuo atveju nacionalinès konstitucijos paprastai apima daug platesni teisinių santykių spektra, nei ES steigimo sutartys, todèl nacionaliniams konstitu- ciniams teismams savo sprendimuose konstitucines žmogaus teises (šiuo atveju judèjimo laisvę) reikia derinti (subalansuoti) su kitais konstituciniais principais ir vertybėmis, be to, kaip jau buvo minèta, konstituciniai principai negali paneigti Konstitucijos 38 str. 3 dalyje numatytos normos dèl santuokos, kaip vyro ir moters sutarties. Tuo tarpu Europos Sajungos Teisingumo Teismo ginamu vertybiu spektras yra daug siauresnis, todèl ne tik nacionaliniu konstituciniu teismų jurisprudencija turi būti draugiška ES teisès atžvilgiu (angl. European friendly), bet ir atvirkščiai - ESTT jurisprudencija turètų būti draugiška nacionalinėms konstitucijoms bei konstitucinių teismų doktrinos atžvilgiu. Tokio draugiškumo teisiniu pagrindu galètu būti ne tik ES steigimo sutartyje numatytas subsidiarumo principas, bet ir pagarba nacionalinėms konstitucinėms tradicijoms, kas yra numatyta $2004 \mathrm{~m}$. Lietuvos Respublikos Konstituciniame akte „Dèl Lietuvos Respublikos narystės Europos Sajungoje“.

Taigi, jei šioje konstitucinės justicijos byloje būtų konstatuota Lietuvos Konstitucijos ir ES teisės normų konkurencija, tai reikštų, kad Lietuvos vykdomoji ir legislatyvinè valdžia turètų imtis minètos ES Piliečiu direktyvos ir Lietuvos Respublikos Konstitucijos derinimo iniciatyvos: inicijuoti atitinkamą Direktyvos arba Lietuvos Respublikos Konstitucijos 38 straipsnio Pataisos procedūrą. Tačiau Konstitucinis Teismas, pats aiškindamas istatyme vartojamą "sutuoktinio" termina, negali nepaisyti Konstitucijos 38 straipsnyje numatytos vyro ir moters santuokos sampratos. 


\section{KELETAS IŠVADŲ IR APIBENDRINIMŲ}

Šiame straipsnyje, analizuojant vieną Konstitucinio Teismo nutarimą, trimis skirtingais tyrimo „pjūviais“ buvo keliamas klausimas dèl galimybės Migracijos departamentui pagal ịstatymą „Dèl užsieniečiu teisinès padèties" suteikti laikiną leidimą gyventi Lietuvoje „šeimos susijungimo" pagrindu užsienio valstybès piliečiui, kuris užsienio valstybèje teisètai sudare santuoką su tos pačios lyties Lietuvos piliečiu. Visos trys perspektyvos leido prieiti neigiamą atsakymą i aukščiau iškeltą klausima, o jos apibendrinimus galima būtų formuluoti taip:

1. Pagal Lietuvos Respublikos Konstituciją šeimos samprata yra gerokai platesnè nei santuokos konstitucinè samprata, nes apima ne tik sutuoktiniu bet ir nesusituokusių vyro ir moters (ar vieno iš jų) bei jų vaikų tarpusavio santykius.

2. Pareiškejjas (LVAT) kreipimesi šioje konstitucinès justicijos byloje kèlè klausimą dèl Konstitucijos 38 straipsnio 3 dalies normos atitikimo kai kuriems konstituciniams principams. Jau vien dèl tokio kreipimosi vidinio prieštaravimo bei dèl to, kad Konstitucinis Teismas nenagrinejja kreipimųsi dèl Konstitucijos nuostatu tarpusavio santykio, Konstitucinis Teismas turejjo prašyti patikslinti kreipimąsi arba atsisakyti ji nagrinèti.

3. 2019 m. sausio 11 d. Konstitucinio Teismo nutarime, sprendžiant įstatymo Dèl „Užsieniečių teisinio statuso“ nuostatu atitikties Konstitucijai klausima, pagrindinis dèmesys turëjo būti teikiamas konstitucinei santuokos sampratai, kuri kyla iš 38 str. 3 dalies normos. Todèl İstatyme „Dèl užsieniečių teisinès padèties" vartojamas terminas "sutuoktinis“ Lietuvos teisinèje sistemoje negali turèti skirtingos reikšmès nei ta, kuri nustatyta Konstitucijos 38 staipsnio 3 ir 5 dalyse.

4. $2019 \mathrm{~m}$. sausio $11 \mathrm{~d}$. nutarime Konstitucinis Teismas nukrypo nuo ankstesnès savo konstitucinès šeimos sampratos, suformuluotos $2011 \mathrm{~m}$. rugsejo $28 \mathrm{~d}$. nutarime, ivesdamas novelą kad konstituciné šeimos samprata yra neutrali lyties požiūriu, ir tai padare, be kita ko, remdamasis ES teisès nuostatomis. Straipsnyje pritariama, kad Konstitucinis Teismas gali keisti savo precedentus, tačiau tam būtina, kad jis toki savo sprendimą nukrypti nuo precedento konstituciškai pagristų. Dèl šios priežasties Teismo teigini apie konstitucinę šeimos samprata, kaip „neutralią lyties požiūriu“, reikètų suprasti ne šeimos partneriu, o Konstitucijos 38 str. 2 dalyje minimo motinystès, tèvystès ir vaikystės konstitucinio instituto (t. $y$. tèvų-vaikų santykių) ribose.

5. Konstituciniu principu ir konstitucinių normų tarpusavio konkurencijos atveju - bendro pobūdžio konstituciniai principai negali „,nurungti“ konstitucinių normų. Kitaip tariant, Konstitucijos 38 str. 3 dalyje suformuluotos normos, kad ",santuoka sudaroma laisvu vyro ir moters sutarimu", negalima paneigti apeliuojant $i$ asmenu lygiateisiškumo, teisinès valstybès, asmens orumo bei kitus konstitucinius principus.

6. Teisminio dialogo fenomenas, kaip ir teismo precedento institutas, yra svar- 
bus šiuolaikinės demokratinès teisinès valstybės, garantuojančios žmogaus teisiu apsauga, elementas, kuris leidžia sustiprinti teisminès valdžios nepriklausomumą kitų valdžiu atžvilgiu. Tačiau Konstitucinis Teismas, interpretuodamas Lietuvos Respublikos Konstitucijos normu ir principu turini, negali tiesiogiai remtis ES teise, Europos teismu doktrina bei kitu šalių konstituciniu teismų doktrina (juo labiau - Europos Tarybos institucijų rezoliucijomis ir rekomendacijomis), nepažeisdamas Konstitucijos viršenybès principo.

7. Lietuvos Respublikos Konstitucija negali būti aiškinama sociologinio ar ideologinio pobūdžio argumentais, todèl kritiškai turètų būti vertinama Konstitucinio Teismo šiame nutarime pateikiami vertinimai apie „vyraujančios daugumos visuomenès narių nuostatas ar stereotipus“. Analogiškai turètų būti vertinamas ir Konstitucinio Teismo bandymas Konstitucijos 29 straipsnyje ittvirtintą asmenų lygiateisiškumo principą sieti su tokiomis sąvokomis, kaip asmenu „lytine tapatybè ir (ar) seksualinè orientacija", kurios nèra vartojamos nei Lietuvos Konstitucijoje, nei kituose Lietuvos teisès norminiuose aktuose.

\section{Literatūra}

Alexy Robert. 2010. Theory of Constitutional Rights. Oxford University Press.

Dworkin Ronald. 2004. Rimtas požiūris i teisę. Vilnius: Lietuvos rašytojų sajungos leidykla.

Dworkin Ronald. 2005. Teises imperija. ALK.

Danelienè Ingrida. 2019. Who is entitled to the right to respect for family life under the European Union law? Teise. Nr. 110: 38.

Gricius Paulius. 2018. Europos Sąungos teisès taikymo tipai Lietuvos Respublikos Konstitucinio Teismo jurisprudencijoje. Teise, t. 109: 50-68.

Jarašiūnas Egidijus. 2008. Kelios mintys apie Lietuvos dalyvavimo tarptautiniuose santykiuose konstitucinius pagrindus. Teise besikeičiančioje Europoje. Law in the changing Europe. Le droit dans une Europe en changement. Liber Amicorum Pranas Kūris. MRU.

Jarukaitis Irmantas. 2011. Europos Sajunga ir Lietuvos Respublika: konstituciniai narystès pagrindai. Justitia.

Kūris Egidijus. 2001. Konstituciniai principai ir Konstitucijos tekstas. Jurisprudencija, t. 23(15): 46-70;

Kūris Egidijus. 2002. Konstitucijos dvasia. Jurisprudencija, t. 30(22): 16-31;

Kūris Egidijus. 2002. Lietuvos Respublikos Konstitucijos principai, Lietuvos konstitucine teise. Lietuvos Teisės Universitetas.
Kūris Egidijus. 2004. Ekstranacionaliniai veiksniai Lietuvos Respublikos Konstituciniam Teismui aiškinant Knostituciją. Teise. T. 50: 78-93.

Lietuvos konstitucionalizmo istorija. Istorine Lietuvos Konstitucija. 2016. (Kolektyvinė monografija). VU.

Lietuvos konstitucine teisè. 2017. (Autoriu kolektyvas). MRU.

Mesonis Gediminas. 2010. Konstitucijos interpretavimo metodologiniai pagrindai. Vilnius: Registru centras.

Sagatys Gediminas. 2010. The concept of family in Lithuanian law. Jurisprudencija, Nr. 1(119).

Šaltinytè Loreta. 2019. Teisès laisvai judèti tos pačios lyties santuokas sudariusiems asmenims pripažinimas Europos Sajungoje ir Lietuvos Respublikoje, Lietuvos teise 2018: esminiai pokyčiai. MRU.

Vaičaitis Vaidotas. 2012. Teisès normatyvumas ir Konstitucinio Teismo kompetencija. Teisè, t. 85.

Vaičaitis Vaidotas. 2017. Country Report - Lithuania. International Law Through the National Prism: The Impact of Judicial Dialogue. Ed. Wyrozumska, A. Łódź: Wydawnictwo Universytetu Łódzkiego: 105-134.

Vaičaitis Vaidotas. 2017. Šiuolaikinè konstitucionalizmo samprata. Teisè, t. 104. 


\section{Teisès aktai}

1. Lietuvos Respublikos Konstitucija. Valstybès žinios, 1992, Nr. 33-1014.

2. $2004 \mathrm{~m}$. liepos 13 d. Lietuvos Respublikos Konstitucinis aktas „Dèl Lietuvos Respublikos narystès Europos Sajungoje“. Valstybės žinios, 2004, Nr. 111-4123.

3. Europos Sajungos pagrindinit teisiu chartija. Europos Sajungos Oficialus leidinys. 201667 /C 202/389-405.

\section{Lietuvos Respublikos \\ Konstitucinio Teismo jurisprudencija}

1. 1995 m. sausio 24 d. Lietuvos Respublikos Konstitucinio Teismo išvada. Valstybès žinios, 1995, Nr. 9-199.

2. 1998 m. gruodžio 9 d. Lietuvos Respublikos Konstitucinio Teismo nutarimas. Valstybès žinios, 1998, Nr. 109-3004.

\section{Europos Sąjungos \\ Teisingumo Teismo sprendimai}

1. 2018 m. birželio 5 d. Europos Sajungos Teisingumo Teismo (Didžioji Kolegija) sprendimas byloje C-673/16 Coman ir kt. 2018 m. liepos 30d./C 268.
4. Lietuvos Respublikos ịstatymas „Dèl užsieniečiu teisinès padèties". Valstybès žinios, 2004, Nr. 732539; TAR 2019-01-08, 2019-00220.

5. Lietuvos Respublikos Teismų įstatymas. Valstybés žinios, 1994, Nr. 46-851; Žin., 2003, Nr. 39-1765; Žin., 2008, Nr. 81-3186.

6. 2008 m. birželio 3 d. Seimo nutarimas „Dèl Valstybinès šeimos politikos sampratos patvirtinimo“. Valstybès žinios, 2008, Nr. 69-2624.

3. 2011 m. rugsëjo 28 d. Lietuvos Respublikos Konstitucinio Teismo nutarimas. Valstybès žinios, 2011. Nr. 1185564.

4. 2019 m. sausio 11 d. Lietuvos Respublikos Konstitucinio Teismo nutarimas. TAR, 2019-01-11, Nr. 2019-439. 